tress syndrome. Lancet Respir Med. 2020;8(4):420-422. doi:10.1016/S2213-2600(20)30076-X.

8. Абатуров О.С., Агафонова О.О., Кривуша О.Л., Нікуліна А.О. Патогенез COVID-19. Здоров'я дитини, 2020;15(2):133-144. doi: 10.22141/22240551.15.1.2020.200598

9. Абдуллаев Р. Ю., Каминская Г. О., Комиссарова О. Г. Сдвиги в системе гемостаза - компонент синдрома системного воспалительного ответа при туберкулезе легких. Врач. 2012, № 2, с. 24-28.

10. Афанасьева А. Н., Одинцова И. Н., Удут В. В. Синдромы эндогенной интоксикации и системного воспалительного ответа: общность и различия. Анестезиол. и реаниматол. 2007 , № 4, с. 67-71.

11. Горенков Д.В., Хантимирова Л.М., Шевцов В.А., Рукавишников А.В., Меркулов В.А., Олефир Ю.В. Вспышка нового инфекиионного заболевания COVID-19: $\beta$-коронавирусы как угроза глобальному здравоохранению. БИОпрепараты. Профилактика, диагностика, лечение. 2020;20(1):6-20. https://doi. org/10.30895/2221-996X-2020-20-1-6-20
12. Дьякова М.Е., Алексеева Н.П., Эсмедляева Д.С., Перова Т.Л., Петрищев Н.Н., Яблонский П.К. Оксид азота - биохимический маркер патогенеза туберкулезного процесса. Туберкулез и болезни легких. 2017;95(2):45-50. https://doi.org/10.21292/2075-12302017-95-2-45-50

13. Земляная Н. А. Клинико-иммунологические особенности туберкулеза легких с множественной лекарственной устойчивостью. Автореф. дисс. на соискание ученой степени к. м. н., Томск, 2007, 24 с.

14. Каминская Г. О., Абдуллаев Р. Ю., Комиссарова О. Г. Оиенка функиионального состояния сосудистого эндотелия у больных туберкулезом легких по результатам биохимического исследования. Туб. и болезни легких. 2013, № 2, с. 42-47.

15. Каминская Г.О., Абдуллаев Р.Ю., Комиссарова О.Г. Особенности метаболической активности сосудистого эндотелия у больных туберкулезом легких. Вестник Российской Академии Медицинских Наук. Том 67, № 11 (2012), с. 29-33.

UDC: $575: 616.24-002.5(624)$

https://doi.org/10.52692/1857-0011.2021.1-69.14

\title{
NATURAL RESISTANCE-ASSOCIATED MACROPHAGE PROTEIN-1 GENE POLYMORPHISMS AND GENETIC SUSCEPTIBILITY TO PULMONARY TUBERCULOSIS IN SUDANESE PATIENTS
}

\author{
Hamdan Zaki HAMDAN ${ }^{1}$, MBBS, associate professor, \\ Yousif Omer ELGAILI I,2, MD, FCCP, associate professor, \\ Waleed Abd Alrazig DOSOGI ${ }^{3}$, MBBS, MSC, associate professor \\ ${ }^{1}$ Al-neelain University, Khartoum, Sudan, \\ ${ }^{2} \mathrm{Al}$-shaab teaching Hospital, Khartoum, Sudan, \\ ${ }^{3}$ University of Kassala, Kassala, Sudan \\ e-mail: Omerlhg1@gmail.com
}

\section{Summary}

Genetic susceptibility to tuberculosis has been investigated worldwide, however a few studies conducted in Sudanese patients. Polymorphisms in NRAMP1 have shown an important association with susceptibility to tuberculosis and progression to active disease. However, whether there is an association of these polymorphisms with pulmonary tuberculosis among Sudanese patients is not investigated yet. The aim of this study was to determine the association of NRAMP1 polymorphisms with development of pulmonary tuberculosis in Sudanese subjects with pulmonary tuberculosis. A casecontrols study (100 in each arm) was conducted at Al-Shaab Teaching Hospital in Khartoum, Sudan during the period of March through September 2017. Genotyping for NRAMP1 (rs3731865) INTR4 and (rs17235409) D543N was done by polymerase chain reaction-restriction fragment length polymorphism (PCR-RFLP).There was no significant difference in the mean $\pm \mathrm{SD}$ of the age and body mass index (BMI) between the cases (tuberculosis) and the controls $[37.7 \pm 4.1$ vs. $35.9 \pm 3.9$ years; $P=0.702]$ and [ $24.6 \pm 1.9$ vs. $24.7 \pm 2.1 ; P=0.444]$, respectively. None of the genotype frequencies investigated in the two polymorphisms were associated with the development of pulmonary tuberculosis. There was a significant association with the development of tuberculosis with illiteracy $P=<0.001$. Gene polymorphisms of NRAMP1 (rs3731865) INTR4 and (rs17235409) D543N were not associated with pulmonary tuberculosis development in this setting. Further study is needed with larger sample size and different design and settings. Increase public awareness about tuberculosis infections and specially in those who are illiterate.

Key-words: genetic susceptibility, tuberculosis, NRAMP1 polymorphisms. 
Rezumat. Polimorfismele genei proteinei macrofage-1 asociate rezistenței naturale și susceptibilitatea genetică la tuberculoza pulmonară la pacienții sudanezi

Susceptibilitatea genetică la tuberculoză a fost investigată la nivel mondial, cu toate acestea, câteva studii au fost efectuate la pacienți sudanezi. Polimorfismele NRAMP1 au arătat o asociere importantă cu predispunerea la tuberculoză şi progresia către boala activă. Cu toate acestea, nu a fost încă investigat dacă există o asociere a acestor polimorfisme cu tuberculoza pulmonară la pacienții sudanezi. Scopul acestui studiu a fost de a determina asocierea polimorfismelor NRAMP1 cu dezvoltarea tuberculozei pulmonare la subiecții sudanezi cu tuberculoză pulmonară. Un studiu de caz-control (100 în fiecare lot) a fost realizat la Spitalul de predare Al-Shaab din Khartoum, Sudan, în perioada martie-septembrie 2017. Genotiparea pentru NRAMP1 (rs3731865) INTR4 şi (rs17235409) D543N a fost realizată prin reacţia de polimerizare în lanţ- polimorfismul de lungime a fragmentului de restricție (PCR-RFLP). Nu a existat nici o diferență semnifi-

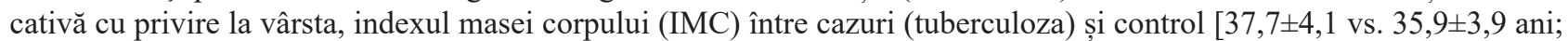
$P=0,702]$ şi $[24,6 \pm 1,9$ vs. $24,7 \pm 2,1 ; P=0,444]$, respectiv. Niciuna dintre frecvențele genotipului cercetate în cele două polimorfisme nu a fost asociată cu dezvoltarea tuberculozei pulmonare. A existat o asociere semnificativă cu dezvoltarea tuberculozei cu analfabetism $P=<0,001$. Polimorfismele genei NRAMP1 (rs3731865) INTR4 și (rs17235409) D543N nu au fost asociate cu dezvoltarea tuberculozei pulmonare în acest studiu. Este necesar un studiu suplimentar cu dimensiuni mai mari ale eșantionului și diferite concepții și setări. A crește gradul de conștientizare a publicului cu privire la infecțiile cu tuberculoză și în special la cei analfabeți.

Cuvinte-cheie: predispunere genetică, tuberculoză, polimorfismele NRAMP1.

Резюме. Полиморфизмы гена макрофагального белка-1, ассоциированного с естественной резистентностью и генетическая предрасположенность к туберкулезу легких у суданских пациентов

Генетическая предрасположенность к туберкулезу изучалась на мировом уровне. Тем не менее, есть ли связь этих полиморфизмов с туберкулезом легких среди суданских пациентов еще не исследовалось. Целью исследования явилось определение связи полиморфизмов NRAMP1 с развитием туберкулеза легких у пациентов с туберкулезом легких из Судана. Изучение случай-контроль (по 100 в каждой группе) было проведено на базе Учебной больницы Аль-Шааб из Хартум, Судан с марта по сентябрь 1917. Генотипирование для NRAMP1 (rs 3731865) INTR4 и (rs17235409) D543N было выполнено с помощью полимеразной цепной реакцией полиморфизма длины рестриктивного фрагмента (PCR-RFLP). Не выявлено значительных различий относительно возраста и индекса массы тела (IMC) в основной (туберкулез) и контрольной группы [[37.7 44.1 против $35.9 \pm 3.9$ лет; $\mathrm{P}=0,702]$ соответственно. Ни у одной из частот генотипа в двух исследованных полиморфизмах не установлена связь с развитием туберкулеза легких. Связь с развитием туберкулеза была с вероятностью ошибки $\mathrm{P}=<0,001$. Полиморфизмы гена NRAMO1(rs3731865) INTR4 и (rs17235409) D543N не были связаны с развитием туберкулеза легких в данном исследовании. Есть необходимость дальнейших исследований на обширном материале с адекватными дизайном и интерпретацией. Повышать осведомленность общественности о туберкулезных инфекциях, особенно среди неграмотных.

Ключевые слова: генетическая предрасположенность, туберкулез, полиморфизмы NRAMP1.

Introduction. Tuberculosis (TB) is a worldwide problem caused by Mycobacterium tuberculosis, Globally, in 2016 there were an estimated 10 million incident cases of TB and 1.6 million deaths (1) . From other prospective, in Sudan as reported by $\mathrm{WHO}$, the rate of TB are 77 cases per 100,000 of the populations with a mortality rate of 12 per 100,000 .

TB infects almost one third of the world population who share the same environmental and nutritional factors, out of them only $10 \%$ develop overt clinical tuberculosis $(2,3)$. This observation supports the claims of principal involvement of host genetic factor_mainly the genes controlling the innate and adaptive immunity_ in development of tuberculosis diseases (4).

The assumption of genetic susceptibility to TB has been raised by numerous researchers, one of them observe the variation in outcome seen in 251 infants after exposure to same dose of a virulent strain of M. tuberculosis instead of BCG vaccine.
Surprisingly, 47 out of these 251 infants did not develop clinical disease, 77 were died, and 127 had a radiological signs of TB (5). Furthermore, different vulnerability among various ethnicities (Black and white) has also been observed (6)clinical, and histopathological evidence suggests that black people are more susceptible to tuberculosis than are white people. The cellular basis of this putative susceptibility was investigated in vitro by comparing responses of blood-derived macrophages from black and white donors to experimental infection with virulent tubercle bacilli. Phagocytes from pairs of black and white donors were infected. The uptake and replication of the tubercle bacilli in these cells were measured by microscopic counts and by CFU counts of bacilli at 0,4 , and 7 days. The effects of donor serum, of 1,25-(OH. Moreover, since last century, twin studies underpin the genetic susceptibility to TB, and this claim has been supported by many researchers recently (7-9). 
At the beginning of the $21^{\text {st }}$ century, the molecular biology discipline witnesses an evolution in the techniques and facility that capable the molecular biologist as well as the clinician to explore the genome and investigate the link between infectious diseases severity and a genetic susceptibility. A candidate gene association study is one of these techniques, which currently are widely used approach to investigate the genetic susceptibility to communicable and non-communicable diseases. Candidate gene association study employs either a population - based case-control design or a family - based design. in former it investigates the relationship between TB and genetic markers by comparing genotype frequencies from unrelated patients and controls. While in later it makes use of pedigrees and evaluates the transmission of a marker allele from heterozygous parents to their affected children by using the transmission disequilibrium test (TDT) (10)several studies that have sought to show linkage with IDDM by testing for cosegregation in affected sib pairs have failed to find evidence for linkage. As means for identifying genes for complex diseases, both the association and the affected-sib-pairs approaches have limitations. It is well known that population association between a disease and a genetic marker can arise as an artifact of population structure, even in the absence of linkage. On the other hand, linkage studies with modest numbers of affected sib pairs may fail to detect linkage, especially if there is linkage heterogeneity. We consider an alternative method to test for linkage with a genetic marker when population association has been found. Using data from families with at least one affected child, we evaluate the transmission of the associated marker allele from a heterozygous parent to an affected offspring. This approach has been used by several investigators, but the statistical properties of the method as a test for linkage have not been investigated. in the present paper we describe the statistical basis for this \»transmission test for linkage disequilibrium\» (transmission/disequilibrium test [TDT]. Although, candidate gene association study has been overcome by the genome wide association studies (GWAS) but still some benefits are owing to candidate gene association studies which include, financially cost-effective and helpful especially on polymorphisms with low allele frequencies and most particularly in a disease such as TB, for which little GWAS data is available (10)several studies that have sought to show linkage with IDDM by testing for cosegregation in affected sib pairs have failed to find evidence for linkage. As means for identifying genes for complex diseases, both the association and the affected-sib-pairs approaches have limitations. It is well known that population association between a disease and a genetic marker can arise as an artifact of population structure, even in the absence of linkage. On the other hand, linkage studies with modest numbers of affected sib pairs may fail to detect linkage, especially if there is linkage heterogeneity. We consider an alternative method to test for linkage with a genetic marker when population association has been found. Using data from families with at least one affected child, we evaluate the transmission of the associated marker allele from a heterozygous parent to an affected offspring. This approach has been used by several investigators, but the statistical properties of the method as a test for linkage have not been investigated. in the present paper we describe the statistical basis for this \»transmission test for linkage disequilibrium\» (transmission/disequilibrium test [TDT].

$N R A M P-1$ gene is known as natural resistance-associated macrophage protein 1 . It is encoded a trans-membrane protein in the macrophage by which converted to phagocytic vacuole after phagocytosis for a microbes (11). This gene is located in the chromosome number 2 and in the cytogenetic band q35 (12)Salmonella, and Leishmania is controlled in the mouse by a single gene on chromosome 1, designated $\mathrm{Bcg}$, Ity, or Lsh. A candidate gene for Bcg, designated natural resistance-associated macrophage protein (Nramp. This protein is essential in early bactericidal activity of the macrophage. Other function reported and related to NRAMP1protein is that, it may act as a divalent cations transporter that withdraw an iron from inside the vacuole which is essential for the mycobacterium in the DNA replication process (13). According to its vital role in the patency of the macrophage function, it is considered as an important candidate gene for tuberculosis, which is eliminated primarily through macrophages.

Many polymorphisms has been reported in $N R A M P 1$ gene that is associated with pulmonary tuberculosis in West African, Chines and Greek populations (14-16)including mycobacteria. A case-control study was conducted in the Greek population to determine whether NRAMP1 polymorphisms affect the susceptibility to development of overt pulmonary tuberculosis. MATERIAL/METHODS NRAMP1 polymorphisms (3'UTR, D543N, INT4. Mycobacterium tuberculosis the causative agent of TB is an intracellular pathogen as Leishmania donovani a causative agent of visceral leishmaniasis. Both of them share the mechanisms by which the immune system tries to clear them out. Recently, there are some published reports linking visceral leishmaniasis to host genetic factor NRAMP1- in a selected Sudanese population $(1 \overline{7}, 18)$ innate susceptibility to Leishmania donovani, the etiological agent of VL, is controlled by Slc11a1 (formerly Nramp1. in this study we will investigate the association of NRAMP1 gene polymorphism namely D543N (rs17235409) and INT4G/C 
(rs3731865) with the development of pulmonary tuberculosis in Sudanese patients.

Knowing the genetic susceptibility of shifting latent TB to develop overt clinical TB is of paramount importance for care-giver and health planner, as well as epidemiologist and doubtless researchers. Providing such data and information is necessary to underpin and promote the health services and prevention measures especially among those at risk. Therefore, this type of studies in TB field is highly recommended.

\section{Problem statement}

Tuberculosis is an airborne contagious disease caused by M. tuberculosis bacteria; it can affect any part of the body but mainly affects the lung. It is a disease of poverty with $95 \%$ mortality reported from the developing world. Sudan alone carries 11- 15\% of the TB burden in the eastern Mediterranean region (EMRO). According to the World Bank data, the gross national income per capita is $\$ 1500$ with almost $47 \%$ of the population below the poverty line (19). That's mean almost $50 \%$ of the population at risk of developing tuberculosis.

With the recent advances in molecular biology Knowing who at risk of developing tuberculosis based on genetic analysis of paramount importance for care giver and health planners. Such knowledge will lead the treatment choices and drug doses adjustments by what is known a personalized medicine.

\section{Research question}

Are there any genetic susceptibility between pulmonary tuberculosis and NRAMP1 gene polymorphism D543N (rs17235409) and INT4G/C (rs3731865) among Sudanese patients?

\section{Research hypothesis}

\section{Null hypothesis}

There is no relationship between the NRAMP1 gene polymorphism D543N (rs17235409) and INT4G/C (rs3731865) and development of pulmonary tuberculosis.

\section{Alternative hypothesis}

There is a relationship between the NRAMP1 gene polymorphism D543N (rs17235409) and INT4G/C (rs3731865) and development of pulmonary tuberculosis.

\section{Justification}

Although TB has been studied for centuries, it is still responsible for more human deaths than any other single infectious disease. It was declared a global public health emergency by the WHO in 1993. The elucidation of the genetic control of susceptibility to TB is expected to provide new and more effective tools for prevention and control of this problematic disease. However, to date, this field has achieved limited success and many of the genes and mechanisms that determine susceptibility to tuberculosis still remain unidentified. The era of genetic susceptibility is more interesting in studying complex disease like diabetes and heart disease, which involved in clinical practice right now, while genetic susceptibility to tuberculosis is years far away from the clinical practice and epidemiological planning, so more research is needed to provide more insight to this terrible disease.

\section{Objectives}

1. To study association between single nucleotide gene polymorphisms of NRAMPI and susceptibility to pulmonary tuberculosis in Sudanese population.

2. To study the interaction between gene polymorphisms of NRAMP1 and clinical severity of the disease.

\section{Methodology}

Study design: Facility based case-control study.

Study setting. The study conducted at Al-Shaab teaching hospital, Khartoum. Al-Shaab Teaching Hospital is a tertiary level hospital that considered as a reference Hospital for respiratory medicine and cardiology specialty. It is located in capital Khartoum just east to Khartoum Teaching Hospital and West of Dentistry Hospital.

Study population. The cases were patients with pulmonary tuberculosis who recruited from in-patient and out-patient clinic according to diagnostic criteria determined by the American Thoracic Society.

Inclusion criteria. The diagnostic criteria for the presence of TB disease were defined as the presence of at least one of the following:

(i) Clinical and radiological findings consistent with TB disease and positive sputum smears for acid fast bacilli.

(ii) Culture positivity of sputum or bronchial lavage.

Exclusion criteria. Any individuals including cases with active TB and controls had a history of severe pathologies, including HIV infection, cardiovascular disease, asthma or, atopy autoimmune diseases, and cancer will be excluded from the study. The inclusion criteria for the control group are the absence of acute or chronic pulmonary disease and a negative history for TB disease and proof of being healthy.

All cases and control undergo history taking followed by clinical examination. Informed signed consent obtained from cases as well as control.

Sample size calculation. The sample size was calculated with 1: 1 ratio for the cases and the controls and the difference in the proportions of polymorphism of the NRAMPl gene polymorphism between the cases and controls. It was assumed that NRAMPI 
Oligonucleotides and restriction enzymes used for detection of NRAMP1 and gene polymorphisms

\begin{tabular}{|c|c|c|c|}
\hline $\begin{array}{l}\text { Polymor- } \\
\text { phism }\end{array}$ & Primers pairs & $\begin{array}{l}\text { Restric- } \\
\text { tion } \\
\text { Enzyme } \\
\text { used }\end{array}$ & PCR-RFLP Fragments \\
\hline $\begin{array}{c}\text { NRAMP1 } \\
\text { D543N } \\
\text { (rs17235409) }\end{array}$ & $\begin{array}{l}\text { Forward 5'-GCATCTCCCCAATTCATGGT -3 ' Re- } \\
\text { verse 5'- CAGGATAGAGTGGGACAGTT-3' }\end{array}$ & AvaII & $\begin{array}{l}\text { 1. (AA: } 205 b p+39 b p) \\
\text { 2. (GG: } 244 b p) \\
\text { 3. (AG: } 205 b p, 39 b p, 244 b p)\end{array}$ \\
\hline $\begin{array}{c}\text { NRAMP1 } \\
\text { INT4G/C } \\
\text { (rs3731865) }\end{array}$ & $\begin{array}{l}\text { Forward 5'- CTCCCTGCCTCCTCACAGCTTCT -3 } \\
\text { 'Reverse 5'- TCTCACATGGGGCATCCCAAG -3 ' }\end{array}$ & BanII & $\begin{array}{l}\text { 1. (GG: } 247 \mathrm{bp}) \\
\text { 2. (CC: } 94 \mathrm{bp} \text { and } 135 \mathrm{bp}) \\
\text { 3. (CG: } 247 \mathrm{bp}, 135 \mathrm{bp} \text { and } 94 \mathrm{bp} \text { ) }\end{array}$ \\
\hline
\end{tabular}

would be in $12.0 \%$ of the patients with tuberculosis and $3.0 \%$ in control group. This rate was assumed from previous report of the NRAMP1 polymorphism in Sudanese patients with visceral leishmaniasis (17) innate susceptibility to Leishmania donovani, the etiological agent of VL, is controlled by Slc1la1 (formerly Nramp1. This would give the study at least $80 \%$ power and the difference of 0.05 at $\alpha$ level.

Sampling technique. Simple random sampling approach was used.

Methods of data collection. Data were collected by using structured questionnaire.

Study variables: This includes, age, gender, occupation, residency, level of education, number of lung lobe involvement.

DNA extraction. Five $\mathrm{ml}$ of venous blood collected and kept in EDTA containing tube. Genomic DNA were extracted immediately after collection of blood and stored in -20 degree until completing the sample size. DNA extracted from $300 \mu \mathrm{l}$ buffy coats using of TB patients and controls using Wizard Genomic DNA Purification Kit, according to the manufacturer's instructions, and consequently quantified using Nano-drop spectrophotometer (UV-Visible Nano Drop 1000, Thermo Fisher Scientific Inc) and standardized to $50 \mathrm{ng} / \mu \mathrm{l}$.

Determination of polymorphisms and genotyping

Determination of the D543N G/A polymorphism (rs17235409)

The polymorphism investigated by Polymerase chain reaction restriction fragment length polymorphism method (PCR-RFLP). Genomic DNA mixed with the primers (the forward primer: 5/-GCATCTCCCCAATTCATGGT-3/ and reverse primer: 5/CAGGATAGAGTGGGACAGTT -3/). The final PCR products will be incubated with Avall and separated on $2 \%$ agarose gels after staining with ethidium bromide. The allele A creates Avall restriction site yielding two fragments of 205 and $39 \mathrm{bp}$, respective- ly. The allele $\mathrm{G}$ will be identified by the presence of a 244 bp undigested fragment.

Determination of the INT4G/C polymorphism (rs3731865).

The polymorphism in position INT4G/C gene investigated using polymerase chain reaction-restriction fragment length polymorphism (PCR-RFLP) methods. Briefly, Amplification will be perform in a final volume of total DNA extracted, after using the following primers (the forward primer 5/- CTCCCTGCCTCCTCACAGCTTCT -3/, and the reverse primer 5/- TCTCACATGGGGCATCCCAAG -3/). The final extension of the PCR product will subjected for restriction enzyme digestion, using the Ban 11 enzyme. The PCR products will incubate with Ban 11 and then separated on $2 \%$ agarose gels after staining with ethidium bromide. The allele $\mathrm{C}$ creates a Ban 11 restriction site yielding two fragments of 94 and 153 bp. The allele $\mathrm{G}$ will be identified by the presence of undigested PCR fragment $247 \mathrm{bp}$.

\section{Statistical analysis}

Data were entered in the computer using SPSS for windows version 13.0 and double checked before analysis. The associations between the allelic/ genotype frequencies and the clinical forms of the TB, as well as the odds ratio for the susceptibility to infection was obtained by the $X^{2}$ test. Mean (SD) differences between cases and controls were tested by using student t-test. A $P$-value $<0.05$ considered statistically significant.

\section{Ethical approval}

Ethical clearance was obtained from Al-Neelain University Ethics Review Board.

\section{Results}

In this study, 100 patients with pulmonary tuberculosis were enrolled and another 100 healthy subjects enrolled as controls. The overall male to female ratio was $2: 1$. The mean age $\pm \mathrm{SD}$ and $\mathrm{BMI} \pm \mathrm{SD}$ of the cases group versus controls was $[37.7 \pm 4.1$ vs. $35.9 \pm 3.9$ years; $P=0.702]$ and $[24.6 \pm 1.9$ vs. 
Comparing the mean (SD) of the sociodemographic characteristics between patients with tuberculosis and the controls

\begin{tabular}{|l|c|c|c|}
\hline \multicolumn{1}{|c|}{ Variables } & $\begin{array}{c}\text { Pulmonary tuberculosis } \\
\mathbf{( 1 0 0 )}\end{array}$ & $\begin{array}{c}\text { Controls } \\
\mathbf{( 1 0 0 )}\end{array}$ & $\boldsymbol{P}$-value \\
\hline Age, year & $37.7(4.1)$ & $35.9(3.9)$ & 0.702 \\
\hline Sex & $72(72)$ & $67(67)$ & 0.443 \\
Male & $28(28)$ & $33(33)$ & \\
Female & $47(47)$ & $17(17)$ & $<0.001$ \\
\hline Educational level & $39(39)$ & $42(42)$ & \\
Illiterate & $11(11)$ & $17(17)$ & \\
Primary & $3(3)$ & $23(23)$ & 0.444 \\
Secondary & $24.6(1.9)$ & $24.7(2.1)$ & \\
University & & & \\
\hline Body mass index, $\mathrm{Kg} / \mathrm{m}^{2}$ & & & \\
\hline
\end{tabular}

$24.7 \pm 2.1$ years; $P=0.444$ ], respectively table 2 . A significant difference was observed between the cases and control groups regarding educational level. Illiteracy represent $47 \%$. $P=<0.001$, about half of the study group did not receive any education. All of the study and control group reside in Khartoum state.

The genotyping for NRAMP1 D543N showed that, the frequency of AA was observed in $70 \%$ in cases group which is higher than $63 \%$ in controls, however this is not reach the statistical significance threshold and show [OR=1.37 (0.76-2.47); $P=$ 0.295]. While $A G$ genotype was detected in $13 \%$ of the cases lower than $25 \%$ observed in controls group, $[\mathrm{OR}=0.44(0.214-0.938) ; P=0.330]$ which showed a protective effect for AG but not reach statistical significance. GG genotype was detected in $17 \%$ of the patients compared to only $12 \%$ in controls, the OR is not significant $[\mathrm{OR}=1.50(0.677-3.334), P=0.317]$. The frequency of the allele A was found to be $76.5 \%$ among cases group while allele $\mathrm{G}$ was higher among cases group 57\%, [OR=0.94 (0.59-1.49), $P=0.815]$.

The genotyping for NRAMPI INT4G/C showed that, the frequency of genotype GG observed in $74 \%$ of the cases group compared to $67 \%$ of the controls, however, the $\mathrm{OR}$ is not significant $[\mathrm{OR}=0.71(0.38$ $1.31) ; P=0.279]$. The frequency of the GC heterozygote genotype was $23 \%$ in cases group compared to $13 \%$ in control group, the $[\mathrm{OR}=1.99(0.94-4.21)$; $\mathrm{P}=0.069]$. While frequency of the $\mathrm{CC}$ allele observed in $13 \%$ of the controls and $10 \%$ of the cases and $[\mathrm{OR}=0.74(0.31-1.78) ; P=0.507]$. The $\mathrm{G}$ allele is observed in $80.5 \%$ of the controls while the $\mathrm{T}$ allele observed in $21.5 \%$ of the cases, $[\mathrm{OR}=0.88(0.54-1.43)$; $P=0.620]$.

Discussion. The current study set out to answer the question; Are there any genetic susceptibility between pulmonary tuberculosis and NRAMP1 gene polymorphism D543N (rs 17235409) and INT4G/C

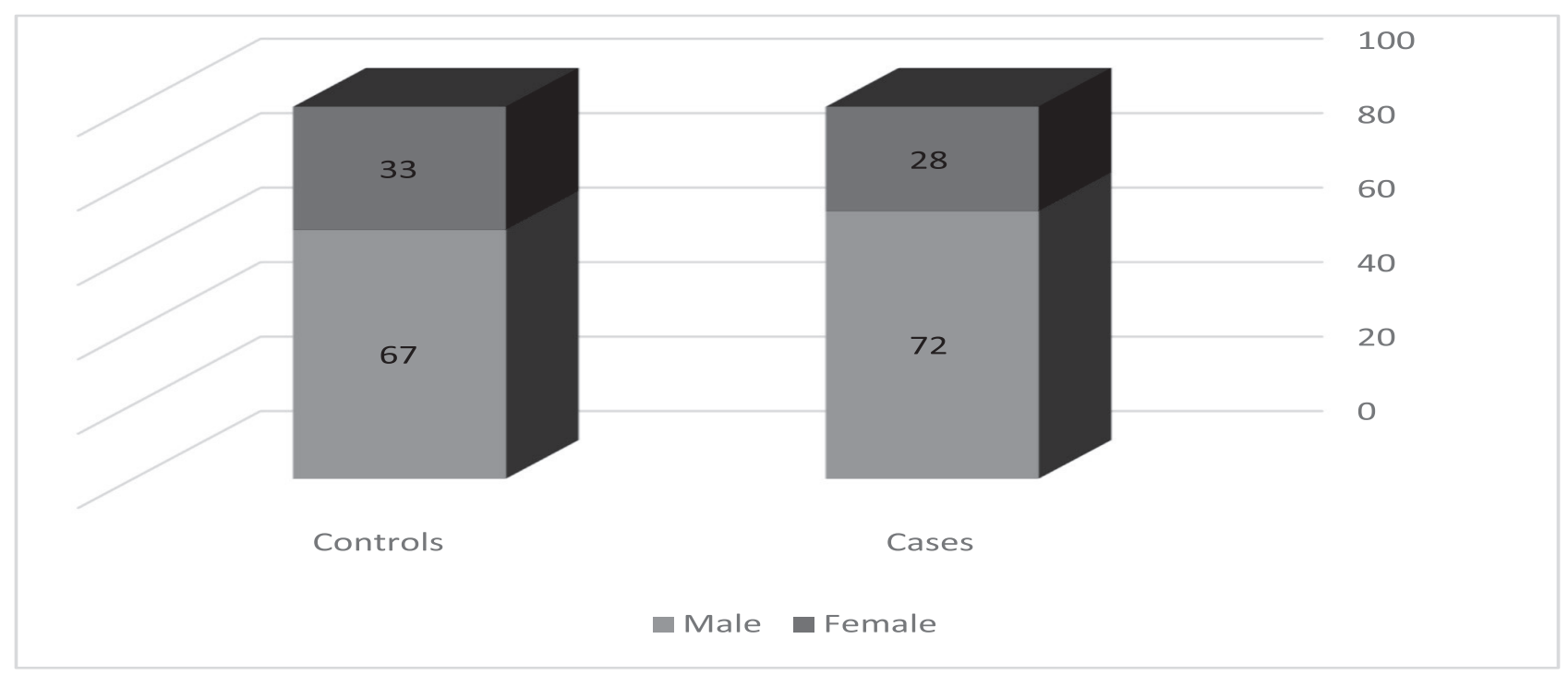

Figure 1. Distribution of sex among cases and controls 


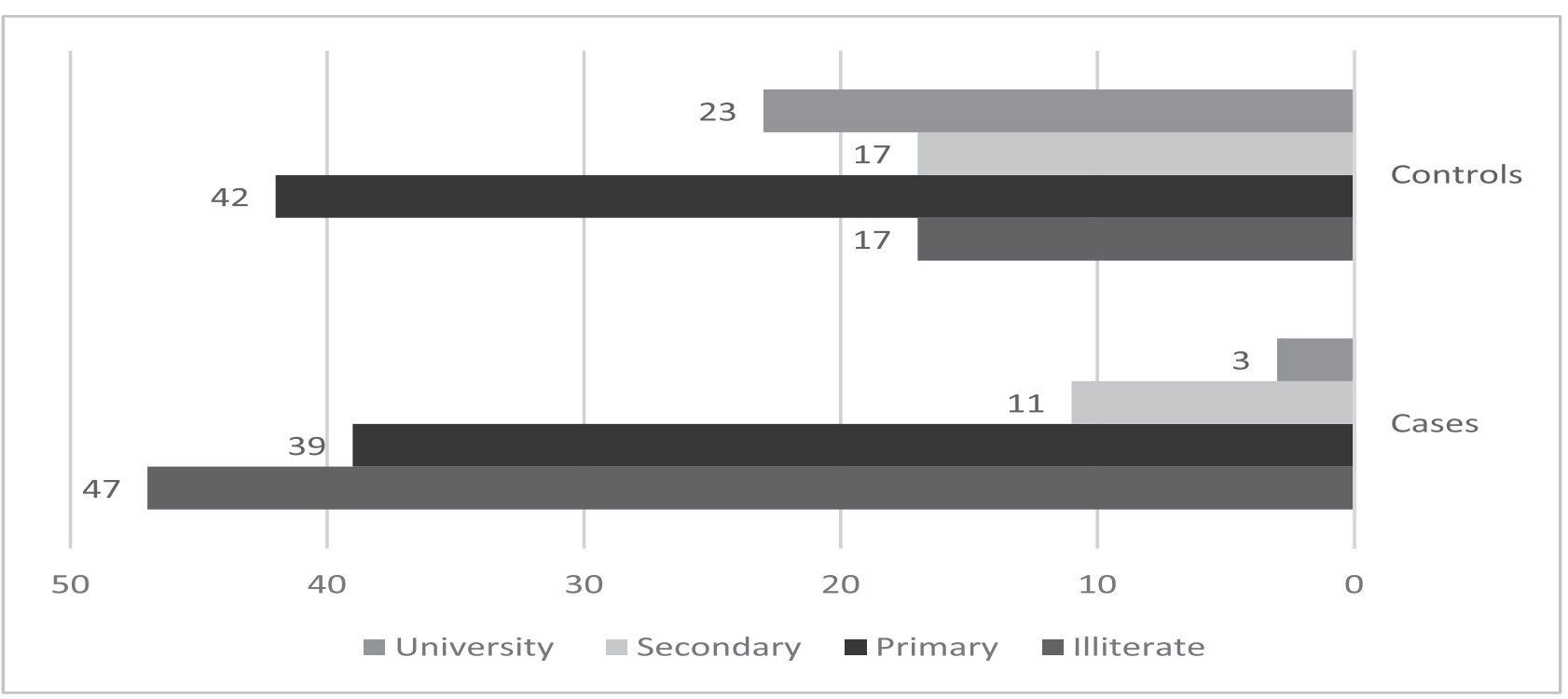

Figure 2. Educational Level among study group and control group

(rs3731865) among Sudanese patients? As we hypothesized that progression of TB infection from latent tuberculosis to clinical pulmonary tuberculosis have genetic susceptibility. This hypothesis is based on the previous documents that confirm the genetic susceptibility for visceral leishmaniasis _ an intra cellular parasite that share the same mechanism of pathogenesis with TB_ in Sudanese patients $(17,18)$ innate susceptibility to Leishmania donovani, the etiological agent of VL, is controlled by Slc11a1 (formerly Nramp1.

The major finding of the current study is that no association were found between NRAMP1 gene polymorphism D543N (rs17235409) and INT4G/C (rs3731865) and development of pulmonary tuberculosis. Our finding in line with other studies reported from Turkey, Brazil, Morocco and Japan (19-20). However, it is inconsistence with other studies reported from Gambia, Tunisia and China (21-22). One of the possible explanations for this inconsistency be- tween these studies is that the genetic diversity among ethnicities could confer various genetic mechanisms underlying the TB susceptibility on the ethnic populations studied. Secondly; perhaps the development of clinical tuberculosis follows the polygenic pattern with involvement of more genes polymorphisms in genes encoding cytokines and proteins that involved in the immune response to tuberculosis like IL-10, TNF- $\alpha$, interferon gamma (INF- $\gamma$ ) and others (23).

Thirdly, this is the first study report the frequency of NRAMP1 gene polymorphisms with pulmonary tuberculosis in Sudan. Other studies reported from Asian, American and population in west and north Africa. The disease susceptibility should be account carefully for the gene-gene interaction and gene-environment interaction (24). Fourthly, we enquiry the patients about diabetes and immune deficiency condition, however, we didn't investigate for diabetes which could be present without the knowledge of the patients. A previous report that

Table 3

Comparing the genotypes and alleles of NRAMP1 D543N G/A (rs17235409) between patients with tuberculosis and the controls

\begin{tabular}{|c|c|c|c|c|}
\hline Genotypes & $\begin{array}{c}\text { Tuberculosis patients } \\
(\mathbf{1 0 0 )} \\
\text { N } \%\end{array}$ & $\begin{array}{c}\text { Controls (100) } \\
\text { N } \%\end{array}$ & OR $(95 \% \mathrm{CI})$ & $P$-value \\
\hline AA & $70 \quad 70$ & $63 \quad 63$ & $1.37(0.76-2.47)$ & 0.295 \\
\hline $\mathrm{AG}$ & 13 & $25 \quad 25$ & $0.44(0.214-1.938)$ & 0.330 \\
\hline GG & 17 & $12 \quad 12$ & $1.50(0.677-3.334)$ & 0.317 \\
\hline Allele A & $153 \quad 76.5$ & 15175.5 & $0.94(0.59-1.49)$ & 0.815 \\
\hline Allele $\mathrm{G}$ & $47 \quad 23.5$ & $49 \quad 24.5$ & & \\
\hline
\end{tabular}

OR: Odds ratio 
Comparing the genotypes and alleles of $N R A M P 1$ INT4G/C (rs3731865) between patients with tuberculosis and the controls

\begin{tabular}{|c|c|c|c|c|}
\hline Genotypes & $\begin{array}{c}\text { Tuberculosis patients } \\
(\mathbf{1 0 0 )} \\
\text { N } \%\end{array}$ & $\begin{array}{c}\text { Controls (100) } \\
\text { N } \%\end{array}$ & OR (95\% CI) & $P$-value \\
\hline GG & $74 \quad 74$ & 67 & $0.71(0.38-1.31)$ & 0.279 \\
\hline GC & 23 & 13 & $1.99(0.94-4.21)$ & 0.069 \\
\hline $\mathrm{CC}$ & 10 & 13 & $0.74(0.31-1.78)$ & 0.507 \\
\hline Allele G & $157 \quad 78.5$ & 80.5 & $0.88(0.54-1.43)$ & 0.620 \\
\hline Allele C & $43 \quad 21.5$ & 19.5 & & \\
\hline
\end{tabular}

OR: Odds ratio

the undiagnosed type 2 diabetic patients in middle east region is almost $60 \%$ (25) Finally, our study sample is powered at $80 \%$ yet we feel it is relatively small. We though all these reasons can justify the current findings.

The NRAMPl gene has been extensively examined to determine its association with tuberculosis (26). It encodes a transmembrane protein that is exclusively expressed in macrophages and polymorphonuclear leukocytes. After phagocytosis, the NRAMP1 protein is rapidly recruited to the phagolysosomal membrane, where it mediates transport of iron and other cations. While iron is an essential mycobacterial nutrient, it is also required by the cell to generate reactive oxygen and nitrogen intermediates. Divalent cations are also essential cofactors for enzymes, such as superoxide dismutase and catalase, which neutralize the cytotoxic effects of the oxidative burst in macrophages (27). Taken together NRAMP1 activates microbicidal responses in the infected macrophage, and it is, therefore, important in the early innate response to mycobacterial infection. in addition, NRAMP1 has central pleiotropic effects on macrophage activation by activating a wide set of immune system related receptors and proteins that include $\mathrm{CXC}$ chemokine $\mathrm{KC}$, interleukin- $1 \beta$ (IL-1 $\beta$ ), inducible nitric oxide synthase (iNOS), major histocompatibility complex (MHC) class II molecules, tumor necrosis factor- $\alpha(\mathrm{TNF} \alpha)$, nitric oxide (NO) release, L-arginine flux, oxidative burst and tumoricidal as well as antimicrobial activity (28). This provide a rational for its involvement in genetic susceptibility to tuberculosis. From clinical point of view r, studies showed that NRAMP1 gene polymorphism associated with clinical severity of pulmonary tuberculosis and development of Multi-drug resistance-tuberculosis (MDR) (29). Furthermore, NRAMP1 gene polymorphism may cause multiple cavitary lesions in lungs and may associated with treatment failure (30). Another document relates the NRAMP1 gene polymorphism with development of extra- pulmonary form of TB rather than pulmonary tuberculosis (21). in light of these mentioned evidence, no doubt that the disease severity and clinical presentation of TB can be affected by the NRAMPl gene polymorphisms.

From molecular prospective, NRAMP1 gene polymorphisms were considred a functional polymorphism. The first polymorphism is located in intron 4 (rs3731865) which is thought to be linked with a splice variant position. Such polymorphism result in either missing exon or gaining an unnecessary amino acid. in either situation it results in defected NRAMP1 protein. The second polymorphism is found in exon 15 (rs17235409) D543N, which result in a missense mutation that the amino acid aspartic acid replaced with asparagine. Both amino acids have different charge and therefore will affect the protein stability and structure.

For the best of our knowledge this is the first study that investigate the frequencies of NRAMP1 gene polymorphism with pulmonary tuberculosis in Sudan. Identification of patients who have the risky allele to develop tuberculosis, treatment failure, MDR-TB and sever from of the disease of paramount importance for all stakeholder in health sector. Although our sample size calculated at $80 \%$ power, however, more sample is needed to guaranteed the result precision. This study has many limitations that we feel it will improve the outcome if avoided in the future. Firstly, the study population is not limited to specific tribe or ethnicity as Sudan has a very diverse population with multiple ethnicity that make it difficult to trace the specific inheritance of polymorphisms. Secondly, the study design is case-control study that will not allow us to know the outcome of disease treatment whether it is relapse, failure, 
complicated to MDR-TB. Thirdly, we did not report the number of lobe infected and whether the lungs contain cavitary lesions or not. Therefore, another large cohort study with specific ethnicity recruitment with careful radiological examination is highly recommended.

Conclusion. The current study failed to show any significant relationship between development of pulmonary tuberculosis and the

\section{References}

1. Tuberculosis [Internet]. [cited 2019 Feb 22]. Available from: https://www.who.int/en/news-room/factsheets/detail/tuberculosis

2. Murray CJ, Styblo K, Rouillon A. Tuberculosis in developing countries: burden, intervention and cost. Bull Int Union Tuberc Lung Dis [Internet]. 1990 Mar [cited 2019 Feb 22];65(1):6-24. Available from: http://www. ncbi.nlm.nih.gov/pubmed/2190653.

3. Vynnycky E., Fine P.E. Lifetime risks, incubation period, and serial interval of tuberculosis. Am J Epidemiol [Internet]. 2000 Aug 1 [cited 2019 Feb 22];152(3):24763. Available from: http://www.ncbi.nlm.nih.gov/ pubmed/10933272

4. Rieder H.L. Clarification of the Luebeck infant tuberculosis. Pneumologie [Internet]. 2003 Jul 15 [cited 2019 Feb 22];57(7):402-5. Available from: http://www. thieme-connect.de/DOI/DOI?10.1055/s-2003-40555

5. Rieder H.L. Clarification of the Luebeck infant tuberculosis. Pneumologie [Internet]. 2003 Jul 15 [cited 2019 Feb 22];57(7):402-5. Available from: http://www. thieme-connect.de/DOI/DOI?10.1055/s-2003-40555

6. Crowle A.J., Elkins N. Relative permissiveness of macrophages from black and white people for virulent tubercle bacilli. Infect Immun [Internet]. 1990 Mar [cited 2019 Feb 22];58(3):632-8. Available from: http://www. ncbi.nlm.nih.gov/pubmed/2106489

7. Simonds. Tuberculosis in twins. London: Pitman Medical Publishing; 1963

8. Kallmann F.J., Reisner D. Twin Studies on the Significance of Genetic Factors in Tuberculosis. Am Rev Tuberc Pulm Dis [Internet]. 1943 [cited 2019 Feb 22];47(6):549-71. Available from: https://www.cabdirect. org/cabdirect/abstract/19432702001

9. Comstock G.W. Tuberculosis in twins: a re-analysis of the Prophit survey. Am Rev Respir Dis [Internet]. 1978 Apr [cited 2019 Feb 22];117(4):621-4. Available from: http://www.ncbi.nlm.nih.gov/pubmed/565607

10. Spielman R.S., McGinnis R.E., Ewens W.J. Transmission test for linkage disequilibrium: the insulin gene region and insulin-dependent diabetes mellitus (IDDM). Am J Hum Genet [Internet]. 1993 Mar [cited 2019 Feb 22];52(3):506-16. Available from: http://www. ncbi.nlm.nih.gov/pubmed/8447318

11. Vidal S.M., Malo D., Vogan K., Skamene E., Gros P. Natural resistance to infection with intracellular parasites: Isolation of a candidate for Bcg. Cell [Internet]. 1993
NRAMP1 gene polymorphisms D543N and INT$4 G / C$. There is a significant relationship of TB with the illiteracy.

Recommendations. Further study is needed with larger sample size, different study design and more sophisticated radiological and molecular analysis. Increase the public awareness about prevention measures transmission of pulmonary tuberculosis specially in illiterate persons.

May 7 [cited 2019 Feb 22];73(3):469-85. Available from: http://www.ncbi.nlm.nih.gov/pubmed/8490962

12. Cellier M., Govoni G., Vidal S., Kwan T., GrouIx N., Liu J., et al. Human natural resistance-associated macrophage protein: cDNA cloning, chromosomal mapping, genomic organization, and tissue-specific expression. J Exp Med [Internet]. 1994 Nov 1 [cited 2019 Feb 22];180(5):1741-52. Available from: http://www.ncbi. nlm.nih.gov/pubmed/7964458

13. Canonne-Hergaux F., Gruenheid S., Govoni G., Gros P. The Nramp1 protein and its role in resistance to infection and macrophage function. Proc Assoc Am Physicians [Internet]. [cited 2019 Feb 22];111(4):283-9. Available from: http://www.ncbi.nlm.nih.gov/pubmed/10417735

14. Stagas M.K., Papaetis G.S., Orphanidou D., Kostopoulos C., Syriou S., Reczko M., et al. Polymorphisms of the NRAMP1 gene: distribution and susceptibility to the development of pulmonary tuberculosis in the Greek population. Med Sci Monit [Internet]. 2011 Jan [cited 2019 Feb 22];17(1):PH1-6. Available from: http://www.ncbi.nlm. nih.gov/pubmed/21169917

15. Wu F., Zhang W., Zhang L., Wu J., Li C., Meng $\mathrm{X}$, et al. NRAMP1, VDR, HLA-DRB1, and HLA-DQB1 gene polymorphisms in susceptibility to tuberculosis among the Chinese Kazakh population: a case-control study. Biomed Res Int [Internet]. 2013 [cited 2019 Feb 22];2013:484535. Available from: http://www.hindawi. com/journals/bmri/2013/484535

16. Bellamy R., Ruwende C., Corrah T., McAdam KPWJ, Whittle H.C, Hill A.V.S. Variations in the NRAMP1 Gene and Susceptibility to Tuberculosis in West Africans. N Engl J Med [Internet]. 1998 Mar 5 [cited 2019 Feb 22];338(10):640-4. Available from: http://www.ncbi. nlm.nih.gov/pubmed/9486992

17. Mohamed H.S., Ibrahim M.E., Miller E.N., White J.K., Cordell H.J., Howson J.M.M, et al. SLC11A1 (formerly NRAMP1) and susceptibility to visceral leishmaniasis in The Sudan. Eur J Hum Genet [Internet]. 2004 Jan 1 [cited 2019 Feb 22];12(1):66-74. Available from: http:// www.nature.com/articles/5201089.

18. Bucheton B., Abel L., Kheir M.M., Mirgani A., El-Safi S.H., Chevillard C., et al. Genetic control of visceral leishmaniasis in a Sudanese population: candidate gene testing indicates a linkage to the NRAMP1 region. Genes Immun [Internet]. 2003 Mar 4 [cited 2019 Feb 
22];4(2):104-9. Available from: http://www.nature.com/ articles/6363927

19. Hanta I., Demirhan O., Hanta D., Kuleci S., Seydaoglu G. Association of the Nrampl gene polymorphisms and clinical forms in patients with tuberculosis. 2012;113(11):657-60.

20. Gao P.S., Fujishima S., Mao X.Q., Remus N., Kanda M.E.T, Dake Y., Bottini N., Tabuchi M., Hasegawa N., Yamaguchi K T., Hopkin J.M., Shirakawa T. Genetic variants of NRAMP1 and active tuberculosis in Japanese populations. Clin Genet. 2000;(58):74-76.

21. Ben-selma W., Harizi H., Letaief M., Boukadida J. International Journal of Infectious Diseases Age- and gender-specific effects on NRAMP1 gene polymorphisms and risk of the development of active tuberculosis in Tunisian populations. Int J Infect Dis [Internet]. 2012;16(7):e543-50. Available from: http://dx.doi. org/10.1016/j.ijid.2011.11.016

22. To G, Africans T. The New England Journal of Medicine variations in the nrampl gene and susceptibility to tuberculosis. 1998.

23. Casanova J.L. Nborn errors ofimmunity to infection: the rule rather than the exception. J Exp Med. 2005;(202):197-201.

24. Vejbaesya S., Chierakul N., Luangtrakool P. NRAMPI and TNF-Alpha polymorphisms and susceptibility to tuberculosis in Thais. Respiratory. 2007;(12):202-6.
25. Hamdan H.Z., Kubbara E., Adam A.M., Hassan O.S., Suliman S.O., Adam I. Urinary tract infections and antimicrobial sensitivity among diabetic patients at Khartoum, Sudan. Ann Clin Microbiol Antimicrob [Internet]. 2015 Dec 21 [cited 2019 Feb 13];14(1):26. Available from: http://www.ncbi.nlm.nih.gov/pubmed/25896611

26. Li H.T, Zhang T.T, Zhou Y.Q, Huang Q.H H.J. SLC11A1 (formerly NRAMP1) gene polymorphisms and tuberculosis susceptibility: a metaanalysis. Int J Tuberc Lung Dis. 2006;10:3-12

27. C. H. Barton, T. E. Biggs, S. T. Baker, H. Bowen and PGP, Atkinson. Nramp 1: a link between intracellular iron transport and innate resistance to intracellular pathogens. J Leukoc Biol. 1999;66(5):757-762.

28. Blackwell J.M., Searle S., Goswami T. Understanding the multiple functions of Nramp1. Microbes Infect. 2000;(2):317-321.

29. Takahashi K., Hasegawa Y., Abe T., Yamamoto T., Nakashima K., Imaizumi K. et al. SLC11A1 (formerly NRAMP1 ) polymorphisms associated with multidrug-resistant tuberculosis. 2008;1:52-7.

30. Abe T., Iinuma Y., Ando M., Yokoyama T., Yamamoto T. et al. NRAMP1 polymorphisms, susceptibility and clinical features of tuberculosis. J Infect. 2003; (46):215 -20.

УДК: 616-002.5(085):615.281

https://doi.org/10.52692/1857-0011.2021.1-69.15

\title{
РЕЗУЛЬТАТЫ ЛЕЧЕНИЯ ТУБЕРКУЛЕЗА С ЛЕКАРСТВЕННОЙ УСТОЙЧИВОСТЬЮ МИКОБАКТЕРИЙ С ПРИМЕНЕНИЕМ БЕДАКВИЛИНА И ДЕЛАМАНИДА
}

\author{
Рафиг БАЙРАМОВ, канд. мед. наук, доцент, Джейхун ИСМАИЛЗАДЕ, канд. мед. наук, доцент, \\ Орхан СУЛЕЙМАНОВ, канд. мед. наук. \\ Азербайджанский Медицинский Университет, г. Баку, Азербайджан \\ e-mail: rafiq-bayramov@mail.ru
}

\section{Резюме}

В статье представлены результаты анализа эффективности и безопасности бедаквилина и деламанида у пациентов с множественным лекарственно-устойчивым туберкулезом (МЛУ-ТБ). Исследовано 73 пациента с МЛУТБ легких, получивших лечение бедаквилином и/или деламанидом в течение $>4$ недель в сочетании с фоновым режимом, рекомендованном ВОЗ. Всем пациентам схема лечения подбиралась индивидуально, согласно тесту лекарственной чувствительности. Средний возраст пациентов составил 49,1 2,77 лет, мужчины составили 46 (63,0\%), женщины - 27 (37,0\%). Пациенты были разделены на 3 группы: I группа - 28 пациентов, которым в схему лечения включили бедаквилин, II группа - 25 пациентов, которым в схему лечения включили деламанид, III группа - 20 пациентов лечились обоими препаратами. Через месяц после лечения количество гемоглобина в сравнении с исходным значением в I группе повысилось в среднем на 29,5\% (р<0,05), во II и III группах на $31,9 \%(\mathrm{p}<0,05)$ и $31,4 \%(\mathrm{p}<0,05)$ соответственно. Среднее значение альбумина повышалось на $13,2 \%, 14,7 \%$ и 20,3\% в I, II и III группах соответственно. Концентрация АЛТ и АСТ в крови после лечения снизилась соответственно на 24,0 и 28,2\% в I группе, на 29,8 и 36,5\% (p<0,05) во II группе, на 32,0 (p<0,05) и 39,0\% (p<0,05) в III 